\title{
The role of strain localization in magma injection into a transtensional shear zone (Variscan belt, SW Iberia)
}

\author{
M. FRANCISCO PEREIRA ${ }^{1 *}$, MARTIM CHICHORRO ${ }^{2}$, CARLOS FERNÁNDEZ ${ }^{3}$, \\ J. BRANDÃO SILVA ${ }^{4} \&$ FILIPA V. MATIAS ${ }^{2}$ \\ ${ }^{1}$ IDL, Departamento de Geociências, Universidade de Évora, Apartado 94, 7001-554 Évora, Portugal \\ ${ }^{2}$ CICEGe, Departamento de Ciências da Terra, Faculdade de Ciências e Tecnologia, Universidade Nova de Lisboa, \\ Quinta da Torre, 2829-516 Caparica, Portugal \\ ${ }^{3}$ Departmento de Geodinámica y Paleontologia, Facultad de Ciencias Experimentales, Universidad de Huelva, \\ Campus Carmen, 21071 Huelva, Spain \\ ${ }^{4} I D L$, Departamento de Geologia, Faculdade de Ciências, Universidade de Lisboa, Edificio C6, Campo Grande, \\ Lisboa, Portugal \\ *Corresponding author (e-mail: mpereira@uevora.pt)
}

\begin{abstract}
This study deals with the interaction between deformation and magmatism in mid- to deep-crustal domains. The relation is analysed between migmatites and shear zones and the spatial distribution of leucogranitoid veins and dykes running through a footwall migmatite system, and reaching a transtensional shear zone operated under amphibolite- to greenschist-facies metamorphic conditions (Boa Fé shear zone, Variscan belt, SW Iberia). Statistical results show that the frequency of width and spacing of the leucogranitoid dykes conform to power-law distributions comparable with observations in volcanic systems. The fractal geometry of the distribution of leucogranitoid dykes highlights the development of a dense framework of thinner weakly or non-mineralized veins and dykes formed at higher nucleation/growth ratios in the footwall migmatite system that contrasts with the emplacement of thicker dykes associated with strongly mineralized thinner veins within the shear zone. The volume of injected leucogranitoid dykes in the shear zone is lower as compared with the footwall and is comparable with an expanding footwall shear zone with non-coaxial flow and volume increase. The Boa Fé shear zone seems to form a physical barrier to the transport of magma to the hanging wall.
\end{abstract}

Injection of magma or melt into shear zones formed on continental crust represents the culmination of a long-lived process involving the generation of magma or melt at depth, its ascent and differentiation, and its final emplacement. The search for an overall understanding of what causes this magmatic activity has led geologists to look at the relations between migmatite systems and processes of magma or melt distribution and their movement through the crust (Brown 1994; Passchier et al. 1996, and references therein; Sawyer 2001). Studies of partially molten rocks based on field observations in high-grade metamorphic terranes (e.g. Sawyer 1996; Ghosh \& Sengupta 1999; Vernon \& Paterson 2001; Marchildon \& Brown 2003) and those involving modelling techniques (e.g. Grujic \& Mancktelow 1998; Rosenberg \& Handy 2001; Druguet \& Carreras 2006) indicate that shearing plays an important role in melt flow. Field examples have shown that melt distribution is associated with complex networks formed by linked compaction, shear and dilation bands (e.g. Brown 2007). These networks act as potential flow channels generated synchronously with shearing (e.g. Brown 1994; Oliver \& Barr 1997; Brown \& Solar 1998). Some workers have suggested that veins and dykes that contain transported melt and magma are scale-invariant (e.g. Tanner 1999; Bons et al. 2004, 2009; Brown 2005; Bonamici $\&$ Duebendorfer 2010) but there is some disagreement on this (e.g. Marchildon \& Brown 2003).

The aim of this paper is to contribute towards a better understanding of the role of strain localization in magma injection into a ductile shear zone. We have studied the spatial arrangement of leucogranitoid dykes injected in the footwall of and within the transtensional Boa Fé shear zone, a Variscan structure of the Évora Massif (SW Iberia; Carvalhosa 1983; Pereira et al. 2007, 2009a; Figs 1 and 2).

Two study areas were analysed. The first of these is a particularly well-exposed, subhorizontal $105 \mathrm{~m}$ long outcrop of diatexites of the Évora high-grade metamorphic terranes, located in the Almansor stream (Figs 1-4). The rocks forming this outcrop show evidence of a complex mingling of magmas resulting from injection of mantle-derived melts into host diatexites (Pereira \& Lucio 2007; Moita et al. 2009) close to the Boa Fé shear zone (Figs 3 and 4). A microstructural analysis of the diatexites and dykes was conducted (Fig. 5a-c). The orientation, thickness and spacing of dykes were measured along scan-lines, and the results were analysed statistically (Fig. 6).

The second study area, designated Casas Novas (Boa Fé shear zone; Figs 1 and 2), consists of pelitic and quartzofeldspathic gneisses injected by concordant and discordant leucocratic veins and dykes (Chichorro 2006; Figs 5d-f and 7). To describe melt and magma flow we used fractal geometry; this is a powerful tool for describing complex natural patterns and the dynamic processes leading to them (e.g. Kruhl 1994). The findings obtained using fractal analysis (1) facilitate the comparison of spatial arrangements, and are useful for establishing and testing models of the formation of spatial arrangements (e.g. Bons et al. 2004), and (2) could be used as an exploration tool in mineralized areas (e.g. Monecke et al. 2001).

To understand the effect of strain localization during the emplacement of leucogranitoids into the Boa Fé shear zone, 3D modelling of the spatial arrangement of dykes at depth was performed. The results 